DOI: $10.26693 / \mathrm{jmbs} 05.05 .293$

UDC 37.091.3:[577.2+575](437.3+437.6+477)

Khrypunova Tetiana

\title{
MOLECULAR BIOLOGY AND GENETICS TEACHING AT DIFFERENT LEVELS OF EDUCATION
}

\author{
Charles University in Prague, $2^{\text {nd }}$ Faculty of General Medicine, Prague, \\ Czech Republic
}

tanyatatatata@yandex.ua

This article is focused on mapping out the form and extent of education of genetics and molecular biology in high schools in Czech Republic and impact of liberalization of education compared to education in Slovac Republic, where education is partly liberalized, and Ukraine, where education is centralized. We have evaluated the available literature, subjective satisfaction of students and retrospective evaluation from absolvents of adequacy of education according to further studies on universities or colleges. In this article we concentrated on gymnasiums and lyceums, because genetics and molecular biology is taught (as separate disciplines) in these types of school and relevant part of students continue studying them in colleges and universities. Among the students of universities who answered the questions of our questionnaire were students of the biological, biochemical and medical faculties, because they were the ones who continue to study these subjects in universities.

Material and methods. Our research was based on studying the available literature concerning current legislation of the selected countries (mainly the difference between education systems of countries), as well as surveys among middle and high school students, university students and secondary school teachers in the form of a questionnaire. We are aware of the fact that the amount of data we have obtained in the research is not entirely sufficient to create a picture of the overall situation, but we hope that the obtained data will still provide some insight into the situation as a whole. According to collected data we have divided taught topics into several categories: depending on the extent and depth of immersion in the topic of teaching; the degree to which they are understandable to students; and the degree to which the topics are sufficient for further study at universities. We compared the results of the above countries and outlined the relationship between them.

Conclusion. We noted several changes that had occurred in education under the influence of the liberalization.

Keywords: genetics, molecular biology, education of biology, gymnasia education, education in the Czech Republic, education in the Slovak Republic, education in Ukraine
Introduction

The form of education in the Czech Republic, Slovak Republic and Ukraine

Teaching is significantly liberalized in the Czech Republic. Schools follow the "Framework Curriculum", which is published by the Ministry of Education of the Czech Republic and prescribes the topics to be covered for the individual subjects and the classes (years of study), where applicable, in which the subject have to be taught. The form of instruction, the number of teaching hours, the curriculum and the use of aids (such as literature) depend on the school government and teachers decision $[1,2,3]$.

In the Slovak Republic, teaching is partially liberalized. Schools must follow the "School Education Program", which is published by the Ministry of Education of the Slovak Republic and stipulates for individual subjects the year in which they have to be taught, the curriculum for that year and the literature that the school is obliged to provide to its students. However, it does not impose a precise form of teaching and precise planning of lessons and topics, and allows teachers to use teaching materials and teaching aids other than those prescribed $[3,4,5]$.

In Ukraine, teaching is centralized. Schools must follow the "School Curriculum", which is published by the Ministry of Education of Ukraine and stipulates for individual subjects the year in which they have to be taught, the school books by which they have to be taught, compulsory literature, as well as the timetable of topics and an exact hourly schedule with an approximate study plan. Teachers can use their own material and discuss additional topics, provided that they also manage to follow the prescribed plan. We would like to draw your attention to the fact that most of the respondents who were interviewed are residents of Donbass, the ATO (anti-terrorist operation) zone territory since 2014, as well as residents of southern and central Ukraine. However, training in these areas goes the same way as before the introduction of the emergency [3, 6].

\section{Available literature}

In the Czech Republic, the following books are among the most frequently used literature: Genetika, Kočárek E., Scientia, 2004; Genetika pro gymnáza Šmarda J., Fortuna Libri, 2003; Odmaturuj z biologie, 
Kolektiv, Didaktis - Brno, 2003. The educational portal www.biomach.cz is also used as well as UNDistorted Science videos from Av Čr. [1, 2, 3].

In the Slovak Republic, the textbook "Biológia pre gymnázia 5, Ušáková a kol., Slovenské pedagogické nakladatel'stvo, 2003" is prescribed by the "School Education Program" [3, 5].

In Ukraine, the "School educational program" prescribes the textbook "Pidruchnik Biology 11th grade P.G. Balan, Yu.G. Verves Academic Rivn. Vidavnystvo: Kiev, Genesa, 2011 rik" [3].

\section{Obtained data and their assessment}

\section{The number and type of respondents}

The respondents who took part in our survey and answered all the questions in our questionnaire were 156 university students, more than half of whom were medical students; 368 secondary school students from the Slovak Republic, 226 students from the Czech Republic, and 229 students from Ukraine. There were 19 school teachers from Ukraine, 24 - from the Czech Republic, and 17 - from the Slovak Republic.

The distribution of topics in accordance with the volume and breadth of information, the degree of concept and assimilation by students and the sufficiency for further education at universities

Based on the data obtained from the questionnaires, we divided the topics we asked about into four categories: highly digestible (perfectly understandable), moderately difficult, problematic and less discussed.

We have attributed "Mendel's laws of heredity", "Hereditary diseases", "Mutations, their occurrence and types" to well-digested (absolutely understandable) topics. More than $75 \%$ of students and teachers designated these topics as studied "very detailed" or "detailed"; more than $75 \%$ of teachers designated them as "very well" or "well" understood and assimilated by students; and more than $75 \%$ of university students named them as "absolutely enough" or "enough" studied for further study at the university (Fig. 1).

We classified as medium-difficult topics such topics as "Human karyotype", "Transcription", "Central dogma of molecular biology", "Human Genome Project". More than $75 \%$ of students and teachers designated these topics as "studied in detail" or "studied within the framework of basic concepts", then more than $70 \%$ of teachers designated these topics as "well" or "averagely" understood and assimilated by students and more than $70 \%$ of university students designated them as "enough" or "average-enough" studied for further study at the university (Fig. 2).

We classified as problematic topics "PCR (polymerase chain reaction)", "Gene expression", "Similarities and differences of the human genome", "Gene

Absolutely understandable topics

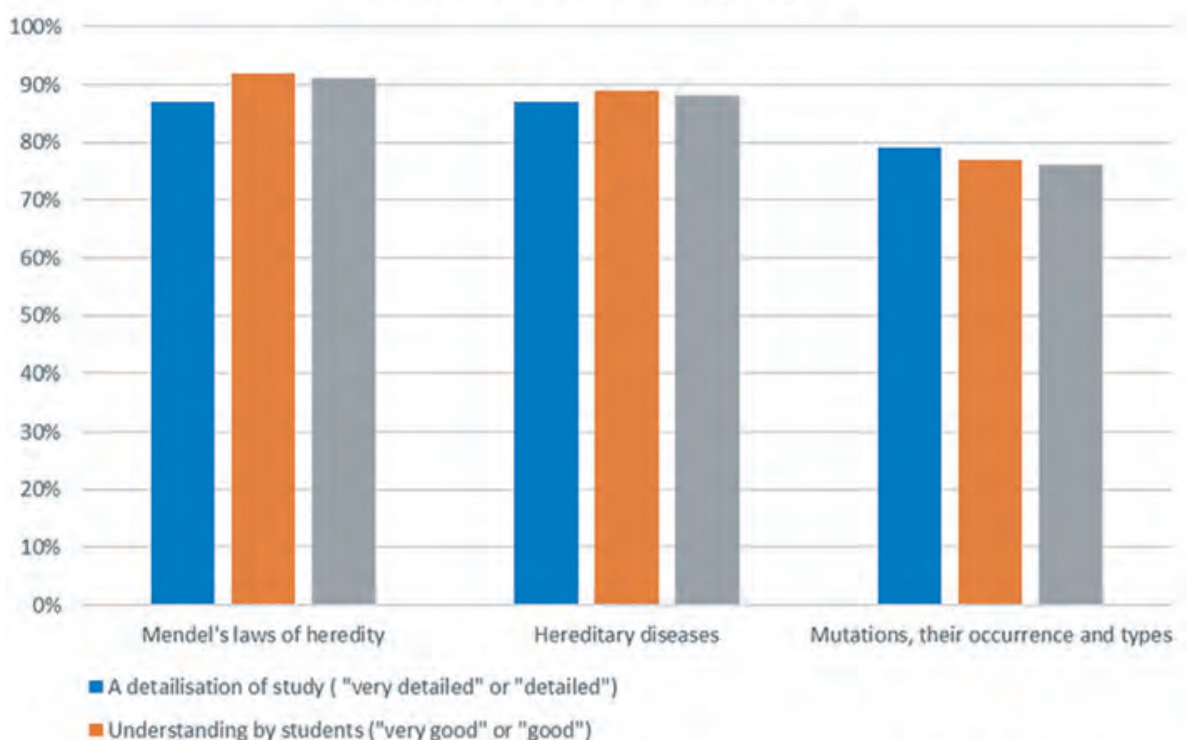

= The depth of immersion in the topic for further study at the university ("absolutely enough" or "enough")

Fig. 1. Absolutely understandable topics

Medium-difficult topics

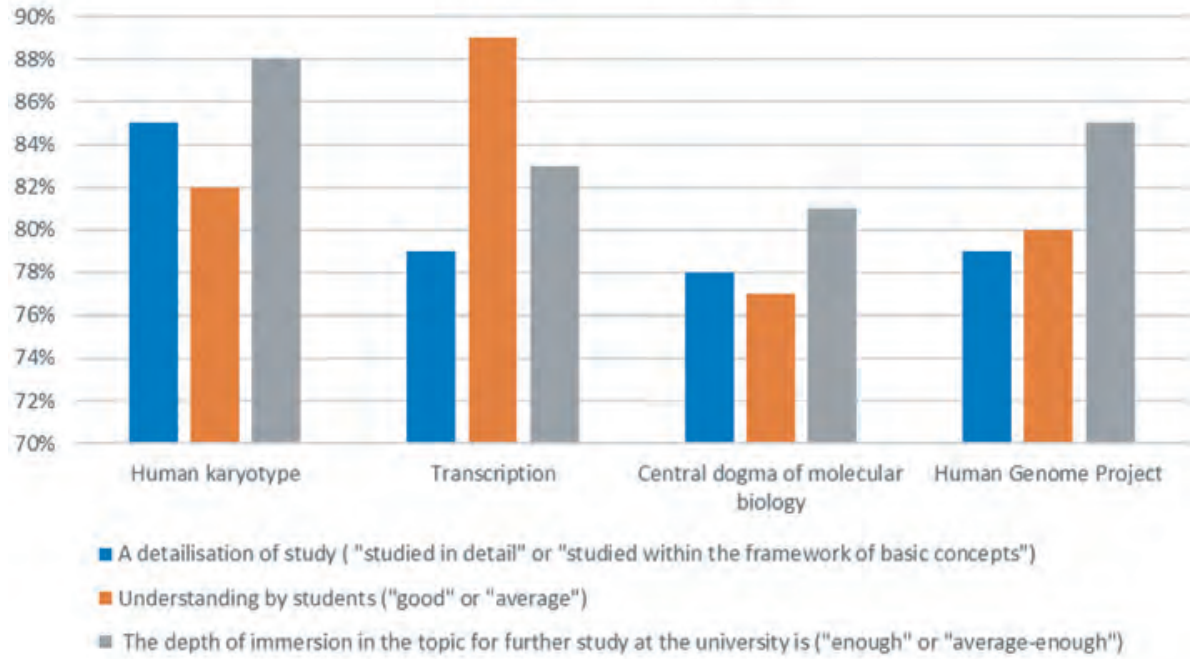

Fig. 2. Medium-difficult topics 
structure", "Coding and noncoding sequences in the human genome". More than $80 \%$ of students and teachers designated these topics as "poorly studied" or "generally unstudied", then more than $80 \%$ of teachers designated these topics as "poorly" understood and assimilated by students and more than $80 \%$ of university students designated them as "absolutely insufficiently" studied for further study at the university (Fig. 3).

To less discussed topics we referred to "Eugenics", "Ethical issues of molecular biology", "History of genetics". More than $75 \%$ of students and teachers designated these topics as "poorly studied" or "generally unstudied", however more than $80 \%$ of teachers designated these topics as "very good" or "well" understood and assimilated by students and more than $75 \%$ of university students designated them as "absolutely enough" or "enough" studied for further study at the university (Fig. 4).

\section{Findings \\ The literature review}

High school graduates from all of the countries evaluated the available literature in completely different ways. We believe that this is due to the fact that the students were not only from different countries and regions, but also from different educational institutions and had different teachers (who also contributed to the assessment of literature), but were also applicants from different universities, with a competition of varying complexity for admission. The human factor also paid its role. That is why we were unable to assess objectively the quality of educational literature in these countries.

\section{Assessing the impact of liberalization}

We asked high school students about their satisfaction with the form of education. Pupils from the Czech Republic rated the training better than students from the Slovak Republic and Ukraine. Thus, we conclude that liberalized learning is subjectively more enjoyable for students.
Problematic topics

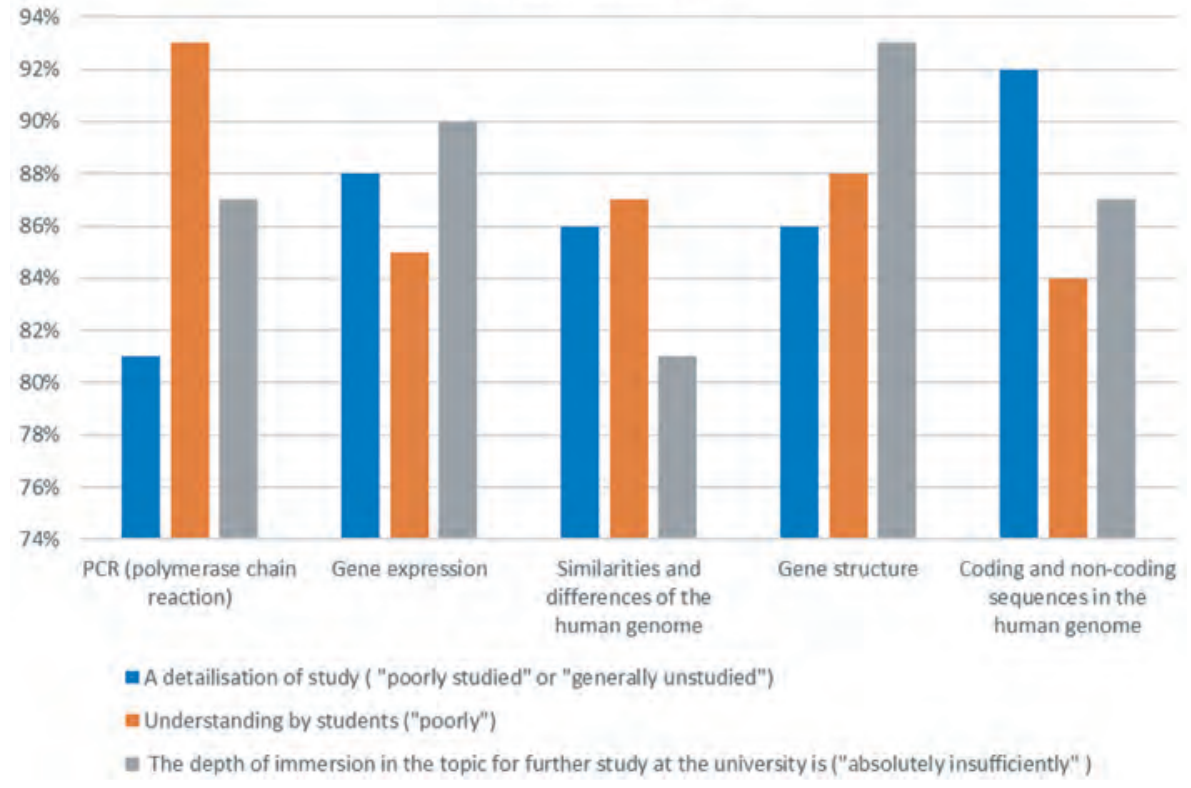

Fig. 3. Problematic topics

Less discussed topics

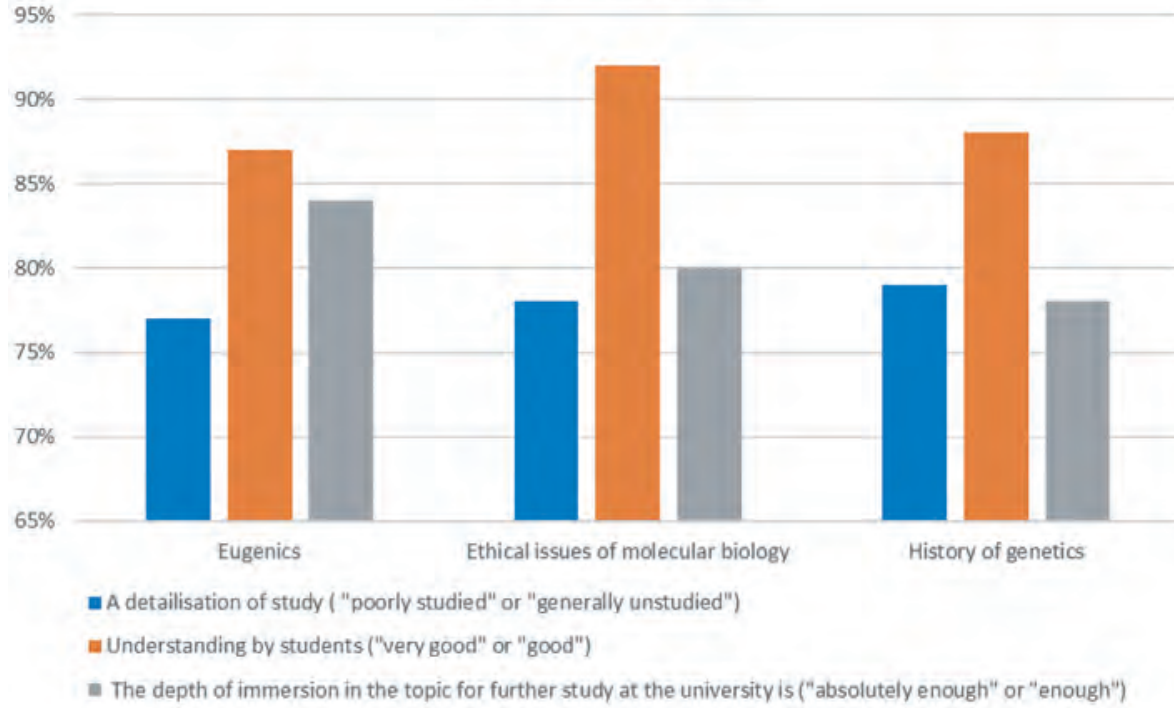

Fig. 4. Less discussed topics

The questionnaires for high school students also included questions to determine their knowledge on specific topics. We assessed the correctness of the answers and compared the results from the Czech Republic, Slovakia and Ukraine.

Students from Ukraine gave much better answers to questions on "well-assimilated (absolutely understandable)" topics and their knowledge favorably differed, while students from the Slovak and Czech Republics showed significantly worse results. Comparing Slovak and Czech high school students, pupils of the Slovak Republic were in the lead. These findings brought us to conclusion that there was a great deal of emphasis on these topics in centralized learning system. 
In the case of questions from "problematic" topics, the trend was exactly the opposite. Czech students gave the best answer, Slovak students were slightly worse, and Ukrainian students showed insufficient knowledge. Based on this, we conclude that teaching by liberalized system is very useful for exploring and addressing deeper and narrower issues.

In the case of questions from "less discussed" topics, we got the same tendency as in "well-learned (completely understandable)" topics. That is why we conclude that the liberalization of learning system leads that students and teachers are focusing only on topics that will be directly needed in further studying, not sufficiently studying general and fundamental topics.

Conclusion and Perspectives. According to our findings, the teaching of genetics and molecular biology in these countries is studied at a fairly high level in secondary schools, liberalization was useful for a deeper study of innovations and deeper topics. We also revealed an insufficient study of the basics of subjects by Czech and Slovak students. We believe that it is necessary to allocate more hours and better teaching materials for the analysis of the topics that we have identified as "problematic"; teachers have to focus exactly on these topics and adjust their teaching to students understanding. Interactive material, electronic devises web-platforms and distance learning can be used for it. It is carried out, for example, by the Ministry of Education of the Slovak Republic in the form of a server www.planetavedomosti.sk.; or popular science materials such as «NEZkreslená věda» created by private organizations in the Czech Republic.

\section{Acknowledgments:}

We would like to thank the Department of Biology and Medical Genetics of the 2nd Faculty of Medicine of Charles University in Prague for the proposal for the development of this topic, as well as Mrs. Lenka Pavlasova, Dr. Sci. (RNDr. Lenka Pavlasová PhD.) the Head of the Department of Biology and Environmental Sciences, Faculty of Natural Sciences, Charles University in Prague for her professional advice; and everyone who took part in our survey and filled in our questionnaire

\section{References}

1. Systém vzdělávání $v$ čr. [Czech]. Available from: https://www.msmt.cz/vzdelavani/skolstvi-v-cr/systemvzdelavani-v-cr

2. Organizace a struktura vzdělávacího systému. 2019. [Czech]. Available from: https://eacea.ec.europa.eu/ national-policies/eurydice/content/organisation-education-system-and-its-structure-21_cs

3. Open-ended questions answers of our questionnaire from respondents who completed the survey. Available from: https://www.surveymonkey.com/mp/comparing-closed-ended-and-open-ended-questions/

4. Školský systém v Slovenskej republike. 2018. [Czech]. Available from: http://www.zilinskazupa.sk/sk/ samosprava/urad-zsk/odbor-skolstva-sportu/kompetencie-hlavne-cinnosti-odboru/skolsky-system-slovenskejrepublike.html

5. CinařD. Komparaceškolských systémů České republiky a Slovenské republiky. 2012.99p. [Czech]. Available from: https://digilib.k.utb.cz/bitstream/handle/10563/18851/cina\%C5\%99_2012_dp.pdf?sequence=1\&isAllowed=y

6. Education System in Ukraine and its Differentiation. 2017. [Ukrainian]. Available from: http://uchebnikirus.com/ pedagogika/pedagogika_-_maksimyuk_sp/sistema_osviti_ukrayini_diferentsiatsiya.htm

\section{Удк 37.091.3:[577.2+575](437.3+437.6+477)}

\section{ВИКЛАДАННЯ МОЛЕКУЛЯРНОЇ БІОЛОГІЇ ТА ГЕНЕТИКИ НА РІЗНИХ РІВНЯХ ОСВІТИ Хрипунова Тетяна}

Резюме. Робота присвячена складанню загальної схеми фрорми і обсягу викладання молекулярної біології і генетики на різних рівнях освіти в Чеській Республіці, а також оцінці впливу лібералізації викладання в порівнянні з викладанням в Словацькій Республіці, де лібералізація не проводилась в такій мірі, і в Україні, де навчання централізоване. В основному оцінено наявність спеціальної літератури, суб'єктивну задоволеність учнів і викладачів викладанням молекулярної біології і генетики на різних рівнях освіти, і ретроспективну оцінку достатності викладання для подальшого навчання в університетах випускниками гімназій і ліцеїв, так як саме в цих типах шкіл викладаються генетика і молекулярна біологія (як окремі дисципліни), і відповідна частина студентів зацікавлена в подальшому вивченні цієї дисципліни. Студенти біологічного, біохімічного та медичних фракультетів вищих навчальних закладів приймали участь в опитуванні, так як саме вони продовжують вивчення молекулярної біології та генетики в університетах. Дослідження складалося головним чином з пошуку доступної літератури для вивчення предметів, і чинного законодавства виділених країн (зокрема системи освіти), а також опитувань серед учнів середніх і старших класів, студентів університетів і вчителів середніх шкіл в формі запитань анкети. Обсяг отриманих даних не $є$ цілком достатнім для створення картини загальної ситуації, але отримані 
дані дозволяють отримати деяке уявлення про ситуацію в цілому. На підставі отриманих даних, теми, обговорювані в процесі навчання, були розділені на кілька категорій: в залежності від ступеня просторості і глибини занурення в тему викладання; ступеня, наскільки вони зрозумілі учням у досліджуваній формі; і ступеня, наскільки вивчені теми $€$ достатніми для подальшого навчання в університетах. Проведено порівняння результатів вищезазначених країн, і намічений взаємозв'язок між ними. Зроблено висновки щодо змін, що відбулися в освіті під впливом лібералізації.

Ключові слова: генетика, молекулярна біологія, викладання біології, викладання в гімназії, освіта в Чехії, освіта в Словацькій Республіці, освіта в Україні.

\section{УДК 37.091.3:[577.2+575](437.3+437.6+477) \\ ПРЕПОДАВАНИЕ МОЛЕКУЛЯРНОЙ БИОЛОГИИ И ГЕНЕТИКИ \\ НА РАЗНЫХ УРОВНЯХ ОБРАЗОВАНИЯ \\ Хрипунова Татьяна}

Резюме. Работа посвящена составлению общей схемы формы и объема преподавания молекулярной биологии и генетики на разных уровнях образования в Чешской Республике, а также оценке влияния либерализации преподавания по сравнению с преподаванием в Словацкой Республике, где либерализация не проводилась в такой степени, и в Украине, где обучение централизовано. В основном оценено наличие специальной литературы, субъективную удовлетворенность учащихся и преподавателей преподаванием молекулярной биологии и генетики на разных уровнях образования, и ретроспективную оценку достаточности преподавания для дальнейшего обучения в университетах выпускниками гимназий и лицеев, так как именно в этих типах школ преподаются генетика и молекулярная биология (как отдельные дисциплины), и соответствующая часть студентов заинтересована в дальнейшем изучении этой области. Среди студентов университетов, ответивших на вопросы нашей анкеты, были студенты биологического, биохимического и медицинских фракультетов, так как именно они продолжают изучение интересующих нас предметов в университетах. Исследование состояло главным образом из поиска доступной литературы для изучения предметов, и действующего законодательства выделенных стран (в частности системы образования), а также опросов среди учащихся средних и старших классов, студентов университетов и учителей средних школ в форме вопросов анкеты. Объем полученных данных не является полностью достаточным для создания картины общей ситуации, но полученные данные позволяют получить некоторое представление о ситуации в целом. На основании полученных данных, темы, обсуждаемые в процессе обучения, были разделены на несколько категорий: в зависимости от степени обширности и глубины погружения в тему преподавания; степени, насколько они понятны ученикам в изучаемой форме; и степени, насколько изученные темы являются достаточными для дальнейшего обучения в университете. Проведено сравнение результатов вышеупомянутых стран, и намечена взаимосвязь между ними. Сделаны выводы относительно изменений, произошедших в образовании под влиянием либерализации.

Ключевые слова: генетика, молекулярная биология, преподавание биологии, преподавание в гимназии, образование в Чехии, образование в Словацкой Республике, образование в Украине.

The authors of this study confirm that the research and publication of the results were not associated with any conflicts regarding commercial or financial relations, relations with organizations and/or individuals who may have been related to the study, and interrelations of coauthors of the article. 